\title{
Cornell axes Elsevier journals as prices rise
}

\section{Jonathan Knight, San Francisco}

A top US research university is set to cancel its subscriptions to several hundred scientific journals published by Elsevier in January, in response to spiralling subscription costs.

The decision by Cornell University in Ithaca, New York, released in a statement last week, caught the attention of library officials at other US research universities who say that they may follow suit.

Netherlands-based Elsevier, which owns a quarter of the global market in scientific and technical journals, played down the importance of the move. Eric Merkel-Sobotta, its head of public relations, declined to comment on the company's negotiations with Cornell, but said that the firm is working hard to accommodate all of its customers. He added that Elsevier's subscription rates are rising by less than $7 \%$ annually, an increase that is necessary to cover the cost of expanding journal content.

Like other large publishers, Elsevier offers 'bundled' subscriptions to its journals along with electronic access. Many institutions have signed such agreements to gain access to large numbers of journals.

"This started out as a very good deal for universities," says Ted Bergstrom, an economist at the University of California, Santa

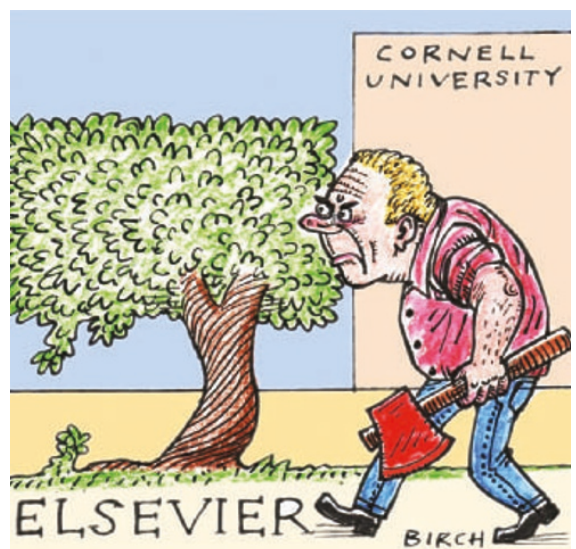

Barbara, who studies journal pricing. But the cost of such arrangements has risen faster than the rate of inflation, and economic woes have put library budgets under pressure.

At Cornell, the increases have forced the library to cut back on its non-bundled titles - but bundles cannot be touched without abrogating the original pricing deal.

Cornell's deal with Elsevier, now priced at $\$ 1.7$ million, consumes a fifth of the university's total periodical budget. When the library tried to cancel individual Elsevier titles, university officials say, the prices of the remaining titles increased significantly, offsetting any savings. "To save a little, you have to cancel a lot," says Cornell's associate collections librarian, Ross Atkinson. Cornell will now return to a title-by-title plan with a vastly reduced number of journals, he says.

Cancellations by other universities are also likely, says Duane Webster, director of the Association of Research Libraries in Washington DC. "Cornell is just the first," he says.

Among those still negotiating is Harvard University, which is unlikely to renew its deal with Elsevier, according to library director Sidney Verba. He says that the price rises will probably result in a large reduction in Elsevier subscriptions.

The University of California has been in negotiations with Elsevier since March over the rising price of online access. In a notice to faculty members dated 15 October, the university's academic senate warned that a reduction in journal access would be likely if no agreement could be reached.

Last month, the faculty senate at the University of California, Santa Cruz, said that Elsevier's pricing was unsustainable. It urged faculty to give up editorships at Elsevier journals and to submit papers elsewhere. Such pressure may force Elsevier to give ground, Bergstrom predicts. "We are going to have an interesting show to watch," he says.

\section{Commercial copying charges hit European academics}
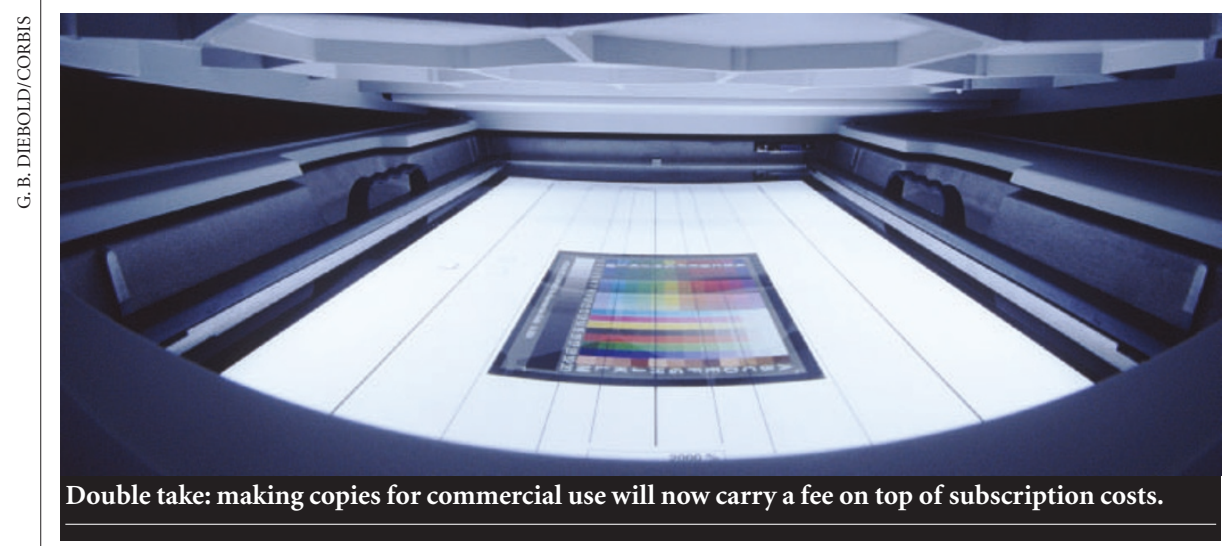

Jim Giles, London

European academics are chafing under a regulation that will require some of them to pay $€ 20$ (US\$24) every time they photocopy a journal paper.

A May 2001 European Union directive on copyright, already implemented in Germany, Britain and four other nations, requires the payment if any "commercial" use of the work is anticipated. Under UK guidelines, such commercial use includes research in writing a book or preparing an article for which the author will be paid.
The UK guidelines, jointly issued in early October this year by the British Library and the London-based Copyright Licensing Agency, say that the fee could also pertain to copies made by students who are sponsored by companies.

"This will be a nightmare for researchers if it is strictly applied," says Roger Elliott, chair of the intellectual-property committee of All European Academies, an Amsterdam-based federation of science and humanities academies. The size of the fee is set by journal publishers, but generally ranges from $€ 7$ to $€ 40$ per copy.

In Germany, where the rules came into force in September, librarians are unclear about what their implications will be. "I'm sure librarians will allow copying in the grey areas," says Harald Müller, library director at the Max Planck law institute in Heidelberg. "But they are a bit scared. They could be breaking the law."

Many library staff say it is too early to assess the impact of the change. But at the Royal Society of Chemistry in London, librarian Nigel Lees fears that the society's document-delivery service is at risk. The service supplied 600 documents a month before the change, but Lees fears that requests will drop once regular customers see their invoices. "I think it is totally unnecessary," says Lees. "We pay once for subscriptions and then the customer pays again."

Publishers say that the intent of the law is to focus on copying by commercial companies. But if academics bear the brunt of the change, publishers could face a backlash, some observers say. "This is another impediment to research by intellectualproperty rights," says Elliott. "And another boost to open-access publishing." 